Anna Romanik

Uniwersytet w Białymstoku

Wydział Filologiczny

Katedra Językoznawstwa Slawistycznego

tel. +48857457450

e-mail: a.romanik@uwb.edu.pl

ORCID ID: https://orcid.org/0000-0002-2733-6503

\title{
Wpływy obce w tekstach czasopism luksusowych w języku rosyjskim, polskim i hiszpańskim (na przykładzie Cosmopolitan)
}

Słowa kluczowe: anglicyzm, czasopismo luksusowe, dyskurs medialny, internacjonalizm, kosmopolityzm

\section{Uwagi wstępne}

Miesięcznik Cosmopolitan wydawany jest w 64 krajach w 35 językach. Dane te świadczą o niezwykłej popularności samego czasopisma oraz gatunku medialnego, jaki reprezentuje. Po raz pierwszy Cosmopolitan ukazał się w Nowym Jorku (USA) w 1886 roku jako czasopismo o charakterze rodzinnym. Przez wiele lat periodyk funkcjonował jako pismo literackie, a w latach 60-ych XX wieku przekształcił się w magazyn modowy adresowany do kobiet. Dzisiejsza wersja Cosmo unika komentowania problemów ze świata polityki czy ekonomii, porusza przede wszystkim tematy związane z modą, rozrywką, karierą zawodową, zdrowiem, ekologią, psychologią itd. Głównym założeniem miesięcznika jest przekaz pozytywnych treści i anonsowanej w tytule ideologii kosmopolitycznej oraz promocja reklam, które stały się integralnym elementem szaty graficznej.

Przedmiotem zainteresowania niniejszej publikacji jest wpływ angielszczyzny obserwowany $\mathrm{w}$ języku czasopisma o zasięgu międzynarodowym - Cosmopolitan. Badanie przeprowadzono z uwzględnieniem trzech wer- 
sji językowych miesięcznika: rosyjskiej, polskiej i hiszpańskiej. Obserwacja zjawiska transferu leksykalnego we wskazanych językach ma swoje uzasadnienie. Z jednej strony, wszystkie te języki znalazły się w strefie silnego wpływu kultury zachodniej, w tym angielszczyzny, nasilonego na przełomie XX i XXI wieku. Z drugie zaś strony, wykazują one znaczące różnice, na przykład, na poziomie grafii (polski i hiszpański posługują się pismem łacińskim, rosyjski - cyrylickim), czy też gramatyki (języki słowiańskie wyróżniają się wybitnie fleksyjną morfologią itd). Cechy dyferencyjne wynikają z przynależności do innych rodzin językowych (hiszpański - romańska rodzina języków indoeuropejskich, polski i rosyjski - słowiańska). Polski i rosyjski reprezentują także inne zespoły języków (polski - zespół zachodniosłowiański, rosyjski - wschodniosłowiański). Badanie wspólnego problemu lingwistycznego na bazie różnych języków może pokazać szerszy kontekst oddziaływania angielskiego na współczesne systemy językowe. Materiał faktograficzny został zgromadzony z numerów opublikowanych w latach 2017-2021. Podjęcie proponowanego tematu wynika z potrzeby uzupełnienia luki w badaniach nad językiem sektora prasy luksusowej (ekskluzywnej), która ma duży wpływ na kształtowanie kanonów normy językowej i świadomości językowej swoich czytelników. Ponadto proces transferu leksykalnego jest zjawiskiem aktualnym, które ma miejsce „tu i teraz”, więc wymaga dodatkowego komentarza. Celem badań jest analiza zgromadzonych anglicyzmów pod kątem sposobu ich adaptacji, a także ustalenie przyczyn popularności form obcych w danej przestrzenie językowej. Dodatkowym założeniem publikacji jest wskazanie powiązań użycia zapożyczeń z koncepcją ideową czasopisma, tzn. z kosmopolityzmem.

Analiza przedstawiona $\mathrm{w}$ niniejszych rozważaniach opiera się na konfrontacji zgromadzonego materiału w ujęciu synchronicznym. Metoda porównawcza trzech wersji językowych czasopisma Cosmopolitan daje możliwość pogłębienia perspektywy badawczej, opisu wpływów współczesnej angielszczyzny na różne języki europejskie. Warto w tym miejscu dodać, że zarówno w Rosji, jak i w Hiszpanii dany magazyn jest wydawany na bieżąco. W Polsce natomiast jego publikacja wygasła z końcem 2019 roku, co było rezultatem kontrowersyjnej decyzji wydawcy miesięcznika - Marquard Media Polska. Uwzględnienie w badaniach polskiej edycji magazynu wynika z faktu, że przez kilka dekad niepodzielnie triumfował w rankingach poczytności i sprzedaży, tym samym, można podejrzewać, wpływał na język swoich czytelników.

Ze względu na popularność i powszechną dostępność czasopism luksusowych (w tym miesięcznika Cosmpolitan) na rynku wydawniczym i szerokie rozpowszechnienie w społeczeństwie na przełomie XX i XXI wieku stały się 
one obiektem zainteresowania środowisk socjologów, medioznawców, a ostatnio także i lingwistów. Język prasy luksusowej ewidentnie kształtuje „gusta” językowe swoich odbiorców, promuje określone trendy mowy pisanej, staje się wzorcem normy literackiej dla szerokiego audytorium.

Przegląd literatury przedmiotu wykazał, że badania językoznawcze sektora czasopism luksusowych stanowią pewnego rodzaju niszę. Sporo publikacji na temat tego rodzaju prasy powstaje w obszarze innych dyscyplin naukowych, na przykład, w prasoznawstwie, które ugruntowało solidną, choć niekompletną bazę teoretyczną dotyczącą cech samego gatunku. Jeśli chodzi o dorobek lingwistów eksplorujących ten temat, to, niestety, jest on skromny, niepełny i wymaga uzupełnienia. Autorami nielicznych prac z zakresu języka czasopism ekskluzywnych są Ė.R. Kaûmova, N.A. Kulešova, A. Kłaczyńska, E.E. Núńez Nogueroles, A. Surendra i in.

\section{Czasopisma luksusowe - cechy gatunku prasowego (aspekt językowy)}

Czasopisma luksusowe, do których zalicza się także magazyn Cosmopolitan, utworzyły specyficzny dyskurs, który umownie można określić jako „dyskurs sektora prasy ekskluzywnej”. Wskazanie jego cech, wbrew pozorom, nie jest łatwe ze względu na wewnętrzne zróżnicowanie tematyczne oraz sporą ilość indywidualnych charakterystyk odrębnych czasopism danego sektora. Elena Zinov'eva rozumienie tego pojęcia ujmuje w sposób uogólniony:

«Глянцевый журнальный дискурс, объединяющий большое количество изданий с самой широкой тематикой (молодежные проблемы, карьера, образ жизни и т.д.), является гендерно-ориентированным, носит имиджево-рекламный и информационно-развлекательный характер (...) При этом дискурс глянцевых журналов отличается своей спецификой: имеет свои собственные коды, формат, стиль, коммуникативную цель, фокус и целевую аудиторию» [Зиновьева 2016, 89].

Badaczka zwraca uwagę także na język omawianego dyskursu, w tym różne strategie komunikacyjne, mające na celu wywołanie pożądanych reakcji docelowego audytorium. Wśród wielu ciekawych „technik perswazyjnych" stosowanych w czasopismach danego sektora medialnego wyodrębnia ona: odwołanie do prototypu - ideału (gwiazdy, bohatera, kultowej marki); łączenie „niekonkretnych” epitetów, modnych słówek i mało znanych terminów z niepełnym zdaniem (atmosfera tajemniczości, nieuchwytnego pojęcia, 
zrozumiałego jedynie przez wybrańców); używanie wielu tropów, figur retorycznych w połączeniu z pięknymi ilustracjami, co tworzy miniprojekcję cudownego życia [Зиновьева 2016, 90]. Autorka podkreśla także, że język prasy ekskluzywnej zawiera mnóstwo zapożyczeń, które wspólnie z leksyką wartościującą, slangiem, nadmierną hiperbolizacją i metaforyzacją tworzą u czytelnika iluzję przynależności do kręgu „wyjątkowych” ludzi.

W dyskursie czasopism luksusowych nie sposób nie dostrzec powszechnej „globalizacji”. Przejawia się ona w języku i prezentowanych treściach, które ulegają wpływowi idealizacji amerykańskiej i brytyjskiej popkultury [Зиновьева 2016, 90]. O globalizacji w sferze języka czasopism danego sektora pisze między innymi Natalia A. Kulešova [2011, 52] - przypisuje ona tej prasie istotną rolę w procesie zapożyczania. Natomiast Û.Š. Bajdžanova [2012, 1642] stawia dość odważną tezę o tym, że rozpowszechnienie i popularyzacja w społeczeństwie zapożyczeń oraz neologizmów jest jedną z podstawowych funkcji prasy luksusowej i w przyszłości upatruje w niej nasilenia procesu neologizacji i transferu z obcojęzycznego areału.

Czasopismo Cosmpolitan należy do gatunku prasy luksusowej, więc jest relatywnym reprezentantem wyżej wymienionych cech dyskursywnych. Niemniej ze względu na indywidualny charakter tego konkretnego magazynu można podjąć próbę uszczegółowienia „dyskursu miesięcznika Cosmopolitan". Rosyjska badaczka, Elmira Kaûmova, pisze:

Авторский коллектив «Cosmpolitan» умело использует набор определенных приемов, позволяющих поддерживать интерес постоянных читателей и привлекать внимание новых. К языковым особенностям организации текста в журнале «Cosmpolitan» относятся повышенная эмоциональность, использование заголовков, основанных на цитировании, цитации и фоновых знаниях; обилие императивных форм глагола, обращение к читателю на «ты», апелляция к истории из жизни или мнению другой женщины, гипертекстовые смыслы и др. [Каюмова 2009, 135].

Analiza trzech różnych edycji miesięcznika Cosmopolitan potwierdza powyższy opis dyskursu danego magazynu, jednocześnie skłania do dodatkowej deskrypcji jego specyfikacji. Każda wersja językowa, pomimo spójności profilu tematycznego i gatunków dziennikarskich, realizacji formy publicity (nadawanie treściom charakteru komercyjnego), zbieżnego stylu wypowiedzi charakterystycznego dla sektora prasy ekskluzywnej (czyt. powyżej), wykazuje też nieliczne różnice. Do nich można zaliczyć, na przykład, sposób prezentacji spisu treści. Wersja polskojęzyczna zawiera skrótowy wykaz tematów przewodnich ,z okładki” oraz zaprezentowany w języku narodowym spis treści uwzględniający tylko stałe działy: Edytorial, Cosmoinspiracje, Uroda, 
Moda, Tylko Ty, Miłość i seks, Warto wiedzieć, Cosmoweekend, O tym się mówi (struktura tytułu z ostatnich publikacji z 2019 roku). Rosyjska wersja (także sporządzona głównie w swoim języku rodzimym) jest bardziej rozszerzona, bowiem w spisie poza tematami wiodaccymi danego numeru znajduje się szczegółowy opis problematyki, w którym przedstawia się zarówno odrębne działy (Здесь \& Сейчас, Карьера \& Деньги, Любовь \& Секс, Стиль \& Мода, Красота \& Здоровье, Психология, Образ жизни), jak i tytuły ważniejszych artykułów, wywiadów, reportaży itd. (struktura z 2021 ro$\mathrm{ku})$. Wpływy obce przejawiają się tu chociażby w zastosowaniu w nazwach działów anglojęzycznego znaku pisarskiego - ampersandu „\&” zamiast rosyjskiego spójnika „и”. Z kolei w hiszpańskiej edycji Cosmopolitan wpływy obce są najbardziej zauważalne, bowiem nazwy regularnych działów są zredagowane w języku oryginału: Hello!, Likes, The look, Beauty, Love, Body, Stories, Style, Money, Discover (struktura z 2019 roku).

Ponadto wszystkie badane edycje Cosmopolitan ewidentnie utrzymane są w konwencji oryginalnego amerykańskiego czasopisma, na którego licencji działają. Prezentują one treści realizujące założenia ideologiczne źródła (globalne, kosmopolityczne), jednak często odnosząc się do lokalnych realiów (wywiady głównie z rodzimymi gwiazdami, opis wydarzeń nie tylko o zasięgu światowym, ale też z obszaru swojego kraju). Każda odrębna edycja zachowuje image i formułę pierwowzoru przy jednoczesnym zachowaniu tożsamości narodowej wyrażanej werbalnie i tematycznie.

\section{Wpływy obce w czasopiśmie Cosmopolitan (językowe przejawy kosmopolityzmu)}

Zasadniczym przesłaniem ideologicznym magazynu (zawartym, nota bene, w tytule) jest kosmopolityzm, który nierozerwalnie łączy się dziś z powszechną globalizacją, jednak obu tych pojęć nie należy ze sobą utożsamiać. W tym miejscu warto uściślić, jak w niniejszej pracy pojmowany jest kosmopolityzm. Idea ta wywodzi się ze starożytnej Grecji od słowa kosmopolita, które oznacza „obywatel świata”. Jak przekonują Maddy Janssens i Chris Steyaert, w myśleniu kosmopolitycznym najbardziej widocznym sposobem pojmowania relacji między uniwersalnością i indywidualnością jest przyznanie pierwszeństwa uniwersalności. Kosmopolityzm, według uczonych, tkwi w przezwyciężeniu zaściankowości, lokalnych poglądów i interesów oraz na podjęciu wspólnego normatywno-filozoficznego zobowiązania do prymatu obywatelstwa światowego nad narodowym, religijnym, kulturowym, etnicznym [Janssens, Steyaert 2014, 3]. Walentyna Dianova [2007, 8] dodaje, 
że kosmopolityzm to typ percepcji rzeczywistości, który najjaskrawiej przejawia się w momentach przejściowych zmian kultury lub w momentach kryzysowych i szczególnie aktualny w epoce globalizacji. Przedstawiony powyżej pogląd stał się myślą przewodnią redaktorów czasopisma i ewidentnie jest realizowany w każdym numerze niezależnie od kraju, w którym jest wydawany. Język także w pewnym zakresie odzwierciedla główny koncept ideowy. Werbalnym dowodem „kosmopolityzacji” czasopisma są między innymi anglicyzmy, które można uznać za narzędzie unifikacji komunikacji międzyludzkiej i zmaterializowany przejaw hegemonii angielszczyzny na świecie.

Eksploracja zgromadzonego materiału pozwala stwierdzić, że zdecydowanej większości anglicyzmów wyekscerpowanych ze wszystkich badanych wersji czasopisma Cosmopolitan można przypisać status internacjonalizmów, które zgodnie z definicją zaproponowaną przez Elenę Marinovą $[2012,31]$ są rozumiane jako: „лексические единицы, имеющие соответствия одинакового происхождения в трех или более неблизкородственных языках". Ilustracją przytoczonej tezy jest poniższa tabela. Zawarto w niej odnotowane w każdej edycji przykłady internacjonalizmów z areału angielskiego. Są to jednostki odnoszące się do różnych grup tematycznych, choć ewidentnie dominuje słownictwo z zakresu mody. Warto jednak dodać, że w badanych numerach charakter międzynarodowy mają również leksemy opisujące współczesne zjawiska socjalne, problemy ekologii, desygnaty związane z nowymi technologiami, komputeryzacją (w tym Internetem, mediami społecznościowymi) itd.

Internacjonalizmy angielskiej proweniencji w rosyjskiej, polskiej i hiszpańskiej edycji magazynu Cosmopolitan

\begin{tabular}{|c|c|c|c|}
\hline $\begin{array}{l}\text { angielski } \\
\text { etymon }\end{array}$ & $\begin{array}{c}\text { reprezentacja } \\
\text { w } \text { rosyjskiej edycji }\end{array}$ & $\begin{array}{c}\text { reprezentacja } \\
\text { w polskiej edycji }\end{array}$ & $\begin{array}{c}\text { reprezentacja } \\
\text { w hiszpańskiej edycji }\end{array}$ \\
\hline beauty & $\begin{array}{l}\text { Самьее и интереснье } \\
\text { и полезнье бьюти- } \\
\text { средства, на кото- } \\
\text { рые стоит обратить } \\
\text { внимание в апреле. } \\
\text { [Совтороlitan апрель } \\
\text { 2020, 180] }\end{array}$ & $\begin{array}{l}\text { Na świecie konkurs ma } \\
\text { 25-letnia tradycje i na- } \\
\text { leży do najbardziej pre- } \\
\text { stiżowych w dziedzinie } \\
\text { beauty. [Cosmopolitan } \\
\text { listopad } 2019,38]\end{array}$ & $\begin{array}{l}\text { La última tendencia be- } \\
\text { auty, ideal para pere- } \\
\text { zosas, ha llegado para } \\
\text { hacerte la vida más fácil. } \\
\text { [Cosmopolitan octubre } \\
2019,60]\end{array}$ \\
\hline blog & $\begin{array}{l}\text { Ищи людей, которьли } \\
\text { был интересен твой } \\
\text { блог, оставь им лайки } \\
\text { и пиши комментарии. } \\
\text { [Cовтороlitan декабрь } \\
\text { 2019, 89] }\end{array}$ & $\begin{array}{l}\text { Czy wtaśnie z zamiłowa- } \\
\text { nia do gotowania założy- } \\
\text { laś blog? Do prowadze- } \\
\text { nia bloga namówili mnie } \\
\text { znajomi. [Cosmopolitan } \\
\text { październik } 2019,30]\end{array}$ & $\begin{array}{l}\text { Cuando empezaste con } \\
\text { el blog de moda, ¿pen- } \\
\text { saste que ibas a llegar } \\
\text { tan alto? [Cosmopolitan } \\
\text { noviembre } 2019,102]\end{array}$ \\
\hline
\end{tabular}




\begin{tabular}{|c|c|c|c|}
\hline $\begin{array}{l}\text { angielski } \\
\text { etymon }\end{array}$ & $\begin{array}{c}\text { reprezentacja } \\
\text { w rosyjskiej edycji }\end{array}$ & $\begin{array}{c}\text { reprezentacja } \\
\text { w polskiej edycji }\end{array}$ & $\begin{array}{c}\text { reprezentacja } \\
\text { w hiszpańskiej edycji }\end{array}$ \\
\hline casual & $\begin{array}{l}\text { Дерзкий и стиль- } \\
\text { ньй комплект из } \\
\text { кэжуал-вещей? Имен- } \\
\text { но так! Просто до- } \\
\text { бавь эффектную обувь, } \\
\text { акиессуары и свежий } \\
\text { взгляд на мир! [Совто- } \\
\text { pоlitaп апрель 2019, 56] }\end{array}$ & $\begin{array}{l}\text { Szlachetny granat skon- } \\
\text { trastowany z pastela- } \\
\text { mi i hastem proeko to } \\
\text { wszystko, czego potrze- } \\
\text { bujesz na jesienne dni } \\
\text { w stylu casual. }[\text { Cosmo- } \\
\text { politan listopad 2019, } 79]\end{array}$ & $\begin{array}{l}\dot{\delta} Y \text { si los vaqueros no fu- } \\
\text { eran tan 'casual' como } \\
\text { piensas? [Cosmopolitan } \\
\text { diciembre } 2019,120]\end{array}$ \\
\hline celebrity & $\begin{array}{l}\text { Топовым иветом губ } \\
\text { по-прежнему остается } \\
\text { красный. Для селеб- } \\
\text { ритис это уже повсе- } \\
\text { дневный лук. [Совторо- } \\
\text { litan ноябрь 2020, 116] }\end{array}$ & $\begin{array}{l}\text { Zdarza się, że ktoś na- } \\
\text { pisze do mnie „,kim jest } \\
\text { w ogóle ta Pieczonka?” } \\
\text { czy „,kolejna staba cele- } \\
\text { brytka”. [Cosmopolitan } \\
\text { grudzień } 2019,25]\end{array}$ & $\begin{array}{l}\text { No sabemos si estas ce- } \\
\text { lebrities están diagno- } \\
\text { sticadas como PAM, pero } \\
\text { de lo que estamos segu- } \\
\text { ras es de que han triun- } \\
\text { fado a pesar. }[\text { Cosmopoli- } \\
\text { tan diciembre } 2019,95]\end{array}$ \\
\hline coach & $\begin{array}{l}\text { Чтобь понять, отку- } \\
\text { да берутся подобнье } \\
\text { настроения - от безде- } \\
\text { лья или огромной люб- } \\
\text { ви, психолог и женский } \\
\text { коуч Алиса Метелина } \\
\text { предлагает следующее. } \\
\text { [Совтороітап сентябрь } \\
\text { 2017, 226] }\end{array}$ & $\begin{array}{l}\text { Do coacha chodzimy } \\
\text { z różnymi sprawami. } \\
\text { Niektórzy z nas szukaja } \\
\text { porad zawodowych, inni } \\
\text { potrzebuja uporzadkować } \\
\text { relacje (miłość!). [Co- } \\
\text { smopolitan październik } \\
\text { 2019, 117] }\end{array}$ & $\begin{array}{l}\text { „(...) Es de sentido } \\
\text { común: cuanta más gen- } \\
\text { te conozcas, más opor- } \\
\text { tunidades tendrás y más } \\
\text { ayuda recibirás", reco- } \\
\text { miendan los coaches } \\
\text { Alcaide y Chica. }[\text { Co- } \\
\text { smopolitan noviembre } \\
2019,111]\end{array}$ \\
\hline coaching & $\begin{array}{l}\text { Конечно, есть при- } \\
\text { родженнье капита- } \\
\text { нь. Это люди с осо- } \\
\text { бой энергией-хариз- } \\
\text { мой, которье росли } \\
\text { в атмосфере родитель- } \\
\text { ской поддержки и, что } \\
\text { немаловажно, одоб- } \\
\text { рения - подчёркивает } \\
\text { Светлана Чумакова, } \\
\text { генеральньй дирек- } \\
\text { тор Международной } \\
\text { академии коучинга, } \\
\text { сертифичированньй } \\
\text { мастер-коуч. [Совторо- } \\
\text { litап март 2017, 98] }\end{array}$ & $\begin{array}{l}\text { Astrolog specjalizujacy } \\
\text { sie w coachingu podpo- } \\
\text { wie ci, jak możesz wyko- } \\
\text { rzystać swój potencjat. } \\
\text { [Cosmopolitan paździer- } \\
\text { nik } 2019,117]\end{array}$ & $\begin{array}{l}\text { Por ejemplo, el } 51 \% \text { de } \\
\text { las compañias estado- } \\
\text { unidenses ha establecido } \\
\text { protocolos para hacerlo, } \\
\text { según la firma especiali- } \\
\text { zada en coaching profe- } \\
\text { sional Challenger, Gray } \\
\text { E Christmas. [Cosmopo- } \\
\text { litan diciembre } 2019,85]\end{array}$ \\
\hline
\end{tabular}




\begin{tabular}{|c|c|c|c|}
\hline $\begin{array}{l}\text { angielski } \\
\text { etymon }\end{array}$ & $\begin{array}{c}\text { reprezentacja } \\
\text { w } \text { rosyjskiej edycji }\end{array}$ & $\begin{array}{c}\text { reprezentacja } \\
\text { w polskiej edycji }\end{array}$ & $\begin{array}{c}\text { reprezentacja } \\
\text { w hiszpańskiej edycji }\end{array}$ \\
\hline cruelty-free & $\begin{array}{l}\text { Помешанные на здо- } \\
\text { ровом образе жизни } \\
\text { и органических про- } \\
\text { дуктах новозеландки } \\
\text { и в косметике от- } \\
\text { дают предпочтение } \\
\text { местным брендам с по- } \\
\text { метками оrganic, vegan } \\
\text { и сrиеlty-free. [Cosmo- } \\
\text { politan май 2019, 157] }\end{array}$ & $\begin{array}{l}\text { Jedno jest pewne, w na- } \\
\text { turze i w modzie nie ma } \\
\text { nigdy pustki. Należy więc } \\
\text { spodziewać się, że zo- } \\
\text { stana opracowane nowe } \\
\text { materiaty cruelty free. } \\
\text { [Cosmopolitan grudzień } \\
2019,77]\end{array}$ & $\begin{array}{l}\text { Y por supuesto, siguien- } \\
\text { do la normativa europea, } \\
\text { son } 100 \% \text { cruelty-free, } \\
\text { es decir, no están te- } \\
\text { stados an animales. } \\
{[\text { Cosmopolitan octubre }} \\
2019,67]\end{array}$ \\
\hline dress code & $\begin{array}{l}\text { Морозьи и метель уже } \\
\text { порядком надоели, по- } \\
\text { ра настраиваться на } \\
\text { весенний лад. На по- } \\
\text { мощь, как всегда, при- } \\
\text { дет твой dress code } \\
\text { - МЕХХ. [Cosmopolitan } \\
\text { март 2021, 36] }\end{array}$ & $\begin{array}{l}\text { Przygotuj sie na zacho- } \\
\text { wywanie określonego } \\
\text { dress code'u (żadne- } \\
\text { go chodzenia w piżamie } \\
\text { do południa) i do wsta- } \\
\text { wania codziennie o tej } \\
\text { samej (niezbyt późnej) } \\
\text { godzinie - tego trzeba } \\
\text { przestrzegać jak w woj- } \\
\text { sku. [Cosmopolitan paź- } \\
\text { dziernik } 2019,67]\end{array}$ & $\begin{array}{l}\text { Si el dress code te exige } \\
\text { ir elegante, el negro nun- } \\
\text { ca falla. }[\text { Cosmopolitan } \\
\text { diciembre } 2019,37]\end{array}$ \\
\hline event & $\begin{array}{l}\text { Юлия Сигунова, } \\
\text { партнер одного из } \\
\text { лучших в России } \\
\text { event-агентств De- } \\
\text { partament Event Mar- } \\
\text { keting. [Cosmopolitan } \\
\text { февраль 2019,74] }\end{array}$ & $\begin{array}{l}\text { Poznatyśmy się kilka } \\
\text { lat temu na światecz- } \\
\text { nej imprezie charyta- } \\
\text { tywnej. Spędzityśmy na } \\
\text { tym evencie razem wiele } \\
\text { czasu i od razu bardzo sie } \\
\text { polubityśmy. [Cosmopoli- } \\
\text { tan grudzień } 2019,23]\end{array}$ & $\begin{array}{l}Y \text { es que hemos acudi- } \\
\text { do a montones de sara- } \\
\text { os, pero sin llegar a ser } \\
\text { coctelaris (specialistas } \\
\text { en eventos). [Cosmopo- } \\
\text { litan noviembre 2019, } 34]\end{array}$ \\
\hline eyeliner/liner & $\begin{array}{l}\text { Если хочешь получить } \\
\text { классический образ, } \\
\text { обведи ллаза чернылм } \\
\text { лайнером и растушуй } \\
\text { линии. [Cовтороlitan } \\
\text { июль-август 2021, 105] }\end{array}$ & $\begin{array}{l}\text { Look dopetnij subtelna } \\
\text { linia na górnej powiece, } \\
\text { stworzona przy użyciu } \\
\text { eyelinera Precise Brush } \\
\text { Liner. [Cosmopolitan } \\
\text { październik 2019, 25] }\end{array}$ & $\begin{array}{l}\text { Rellena poco a poco con } \\
\text { el eyeliner líquido. [Co- } \\
\text { smopolitan noviembre } \\
2019,135]\end{array}$ \\
\hline fashion & $\begin{array}{l}\text { Основной челью показа } \\
\text { бьлло раскрыть потен- } \\
\text { ииал локальных дизай- } \\
\text { неров и брендов, пока- } \\
\text { зать местнылм произ- } \\
\text { водствам, какие трен- } \\
\text { ды и технологии вос- } \\
\text { требовань на мировом } \\
\text { fаshiоп-рынке (...). } \\
{[\text { Соsтороlitaп март }} \\
\text { 2021, 66] }\end{array}$ & $\begin{array}{l}\text { Jednym z nich jest rezy- } \\
\text { gnacja z fast fashion } \\
\text { i zwrócenie się ku zrów- } \\
\text { noważonej modzie, która } \\
\text { opiera się na trzech ha- } \\
\text { stach: recycle, remake, } \\
\text { rewear. [Cosmopolitan } \\
\text { grudzień 2019, 76] }\end{array}$ & $\begin{array}{l}\text { Yo siempre comento que } \\
\text { soy fashion blogger, } \\
\text { que es como empecé } \\
\text { y que es lo que me ha } \\
\text { traído hasta aquí. [Co- } \\
\text { smopolitan noviembre } \\
2019,102]\end{array}$ \\
\hline
\end{tabular}




\begin{tabular}{|c|c|c|c|}
\hline $\begin{array}{l}\text { angielski } \\
\text { etymon }\end{array}$ & $\begin{array}{c}\text { reprezentacja } \\
\text { w rosyjskiej edycji }\end{array}$ & $\begin{array}{c}\text { reprezentacja } \\
\text { w polskiej edycji }\end{array}$ & $\begin{array}{c}\text { reprezentacja } \\
\text { w hiszpańskiej edycji }\end{array}$ \\
\hline influencer & $\begin{array}{l}\text { В мечтах ть блогер, } \\
\text { но не знаешь, в какую } \\
\text { сочсеть податься, ведь } \\
\text { инфлюенсеров и так } \\
\text { полно? [Cosmopolitan } \\
\text { декабрь 2019, 88] }\end{array}$ & $\begin{array}{l}\text { Mimo ogromu produk- } \\
\text { tów dostęnych na ryn- } \\
\text { ku producenci nie zwal- } \\
\text { niaja tempa i zasypuja } \\
\text { nas coraz większa ilo- } \\
\text { ścia nowych kosmetyków, } \\
\text { a influencerki i kosme- } \\
\text { tyczni guru zdradzaja } \\
\text { coraz nowsze sposoby na } \\
\text { zmycie ze skóry wszyst- } \\
\text { kich zanieczyszczeń (...). } \\
{[\text { Cosmopolitan listopad }} \\
\text { 2019, 46] }\end{array}$ & $\begin{array}{l}\text { Asi que, lo queramos } \\
\text { o no, todos somos in- } \\
\text { fluyentes/influencers. } \\
\text { [Cosmopolitan noviembre } \\
2019,16] \\
\text { Eres la única influen- } \\
\text { cer que tiene un festival: } \\
\text { el Dulceweekend, que se } \\
\text { celebra en Barcelona. } \\
{[\text { Cosmopolitan noviembre }} \\
2019,104]\end{array}$ \\
\hline look & $\begin{array}{l}\text { Топовым иветом губ } \\
\text { по-прежнему остаётся } \\
\text { красньй. Для селеб- } \\
\text { ритис это уже по- } \\
\text { вседневньии лук. [Со- } \\
\text { sтороіitan ноябрь } \\
2017,116]\end{array}$ & $\begin{array}{l}\text { Nasza redaktorka Asia } \\
\text { miała w tym miesiacu } \\
\text { zadanie specjalne: stwo- } \\
\text { rzyć świateczne looki } \\
\text { inspirowane stylizacjami } \\
\text { gwiazd. [Cosmopolitan } \\
\text { grudzień } 2019,65]\end{array}$ & $\begin{array}{l}\text { El bolso es otro de los } \\
\text { elementos con el que } \\
\text { podrás añadir el guiño } \\
\text { deco a tu look. [Co- } \\
\text { smopolitan noviembre } \\
2019,48]\end{array}$ \\
\hline make-up & $\begin{array}{l}\text { Современный мейкап } \\
\text { - смелый, иногда чрез- } \\
\text { мерный, даже неакку- } \\
\text { pатный. [Cosтороlitan } \\
\text { ноябрь 2017, 215] }\end{array}$ & $\begin{array}{l}\text { Prawda jest taka, że do } \\
\text { niej przychodzi mnóstwo } \\
\text { dziewczyn na make-up, } \\
\text { więc miałyśmy wiele oka- } \\
\text { zji, by poplotkować, a nie } \\
\text { robi tego. [Cosmopolitan } \\
\text { grudzień } 2019,23]\end{array}$ & $\begin{array}{l}\text { Tras colgar las alas de } \\
\text { Victoria's Secret, Jes- } \\
\text { sica decidió cumplir } \\
\text { su sueño y lanzar Lu- } \\
\text { ma Beauty, especiali- } \\
\text { zada en el cuidado de } \\
\text { la piel y en la estética } \\
\text { no make-up, una de } \\
\text { sus señas de identidad. } \\
{[\text { Cosmopolitan octubre }} \\
\text { 2019, 63] }\end{array}$ \\
\hline must have & $\begin{array}{l}\text { Грамотный русский } \\
\text { язык - это мастхэв. } \\
{[\text { Cоsтороlitan октябрь }} \\
2020,81]\end{array}$ & $\begin{array}{l}\text { Przed świętami musisz } \\
\text { wybrać sié do sklepów Li- } \\
\text { lou po najnowsza dosta- } \\
\text { wę inspiracji. Bransoletki } \\
\text { z sezonowymi hastami to } \\
\text { must have. }[\text { Cosmopoli- } \\
\text { tan grudzień } 2019,78]\end{array}$ & $\begin{array}{l}\text { Son el ultimo must ha- } \\
\text { ve en los gimnasios, ya } \\
\text { que cuentan calorias, } \\
\text { vigilan la respiración... } \\
{[\text { Cosmopolitan noviembre }} \\
2019,89]\end{array}$ \\
\hline outfit & $\begin{array}{l}\text { Подобрала (Настя Ма- } \\
\text { линовская) горячие } \\
\text { аутфить из коллек- } \\
\text { иий нового сезона для } \\
\text { съёмки с Соней Ессь- } \\
\text { ман. [Cовтороlitan сен- } \\
\text { тябрь 2018, 30] }\end{array}$ & $\begin{array}{l}\text { Té் chciatabyś dodać } \\
\text { niecodziennego charak- } \\
\text { teru swoim outfitom? } \\
{[\text { Cosmopolitan grudzień }} \\
2019,65]\end{array}$ & $\begin{array}{l}\text { Las utilizo para expre- } \\
\text { sar mi estado de ánimo } \\
\text { y me divierte que sirvan } \\
\text { para dar un toque di- } \\
\text { ferente a mis outfits. } \\
\text { [Cosmopolitan noviembre } \\
2019,50]\end{array}$ \\
\hline
\end{tabular}




\begin{tabular}{|c|c|c|c|}
\hline $\begin{array}{l}\text { angielski } \\
\text { etymon }\end{array}$ & $\begin{array}{c}\text { reprezentacja } \\
\text { w rosyjskiej edycji }\end{array}$ & $\begin{array}{c}\text { reprezentacja } \\
\text { w polskiej edycji }\end{array}$ & $\begin{array}{c}\text { reprezentacja } \\
\text { w hiszpańskiej edycji }\end{array}$ \\
\hline oversize & $\begin{array}{l}\text { Подбирая жакет, от- } \\
\text { дай предпочтение мо- } \\
\text { дели прямого покроя } \\
\text { и слегка оверсайз. } \\
{[\text { [овтороіitan апрель }} \\
\text { 2020, 124] }\end{array}$ & $\begin{array}{l}\text { Lekko oversize'owe } \\
\text { dzinsowe kurtki to syno- } \\
\text { nim casualowego stylu } \\
\text { lat } 80 . \text { [Cosmopolitan } \\
\text { październik } 2019,52]\end{array}$ & $\begin{array}{l}\text { Las prendas que crea re- } \\
\text { flejan su estilo a la per- } \\
\text { fección: pantalones de } \\
\text { chándal, jerséis over- } \\
\text { size, camisas con es- } \\
\text { tampado military y botas } \\
\text { planas. [Cosmopolitan } \\
\text { noviembre } 2019,67]\end{array}$ \\
\hline performance & $\begin{array}{l}\text { В восемь утра. В мет- } \\
\text { ро. Ну разве что вдруг } \\
\text { самой зачем-то за- } \\
\text { хотелось устроить } \\
\text { этот перформанс. } \\
{[\text { Совтороlitan март }} \\
2021,52]\end{array}$ & $\begin{array}{l}\text { „Pokonać mur" Mariny } \\
\text { Abramović - wspomnie- } \\
\text { nia wybitnej artystki, } \\
\text { ikony performance'u. } \\
\text { [Cosmopolitan listopad } \\
\text { 2019, 18] }\end{array}$ & $\begin{array}{l}\text { A mí me encanta arre- } \\
\text { glarme y montar una } \\
\text { gran performance para } \\
\text { que no haya sólo música. } \\
{[\text { Cosmopolitan diciembre }} \\
2019,108]\end{array}$ \\
\hline post & $\begin{array}{l}\text { Помню, когда начала } \\
\text { писать в Тшіttеr, сде- } \\
\text { лала глупую ошибку } \\
\text { в слове. К счастью, } \\
\text { успела быстро от- } \\
\text { редактировать тот } \\
\text { пост, а иначе страш- } \\
\text { но подумать, как бь } \\
\text { меня затроллили. } \\
{[\text { Совтороlitan апрель }} \\
2018,75]\end{array}$ & $\begin{array}{l}\text { Na samym Instagramie } \\
\text { na twój post z listem za- } \\
\text { reagowato ponad } 80 \text { tys. } \\
\text { osób... [Cosmopolitan } \\
\text { listopad } 2019,91]\end{array}$ & $\begin{array}{l}\text { La matriarca del clan } \\
\text { aseguro que si se trata } \\
\text { de Kim o Kylie, con } 149 \\
\text { y } 147 \text { millones de follo- } \\
\text { wers respectivamente, } \\
\text { la suma económica por } \\
\text { publicar un solo post al- } \\
\text { canza fácilmente las siete } \\
\text { cifras. }[\text { Cosmopolitan no- } \\
\text { viembre } 2019,99]\end{array}$ \\
\hline
\end{tabular}

Z przeprowadzonej analizy czasopisma Cosmopolitan wynika, że każda z badanych wersji językowych (rosyjska, polska i hiszpańska) stanowi platformę, za której pośrednictwem następuje intensywny import anglicyzmów oraz ich popularyzacja. Odnotowane wyrazy angloamerykańskiej proweniencji stanowią niejednorodny zbiór jednostek leksykalnych, zróżnicowanych przede wszystkim pod względem chronologii pojawienia się w języku zapożyczającym (najnowsze jednostki oraz pożyczki o dość ustabilizowanej już pozycji), a także pod względem stopnia przyswojenia w nowym systemie językowym. Przytoczone przykłady pokazują, że część anglicyzmów jest w pełni zasymilowana na poziomie gramatycznym (zakwalifikowana do odpowiedniej kategorii gramatycznej), a w przypadku języka rosyjskiego także na poziomie graficznym (zapisane cyrylicą). Inne natomiast zachowują swoją oryginalną formę i pisownię. Te ostanie (wtręty anglojęzyczne) zajmują we wszystkich językach silną pozycję, stąd warto przyjrzeć im się nieco uważniej. 
W języku hiszpańskim status niezasymilowanych wyrazów obcych jest jasny - nie należą one do systemu leksykalnego języka. W badanym magazynie ich wyalienowanie systemowe na piśmie podkreśla się stosownym zapisem - poprzez zastosowanie kursywy, bądź cudzysłowu. Co ciekawe, w eksplorowanej prasie ilość niezaadaptowanych anglicyzmów przewyższa ilość jednostek przyswojonych przez język. Tezę tę potwierdzają także badania przeprowadzone przez rosyjską iberystkę, N.A. Kulešovą [2010, 37]. $\mathrm{Z}$ punktu widzenia badacza języka, sposób prezentacji najnowszych zapożyczeń w tekstach prasowych (wyodrębnienie graficzne) bardzo ułatwia ich identyfikację i jest swoistym markerem obcego pochodzenia wyrazu lub bardziej złożonej syntagmy.

W języku polskim sytuacja wygląda nieco inaczej, ponieważ niezasymilowane pożyczki „wtapiają” się w tekst ze względu na fakt, że polszczyzna, tak jak hiszpański, posługuje się tym samym pismem, co źródło importu wyrazów obcych, lecz, w przeciwieństwie do języka hiszpańskiego, nie istnieje żaden szczególny zwyczaj ich wizualnego wyróżnienia. Jednym z nielicznych sposobów graficznego zaakcentowania językowej odrębności i obcej proweniencji danej jednostki odnotowanym w polskiej wersji czasopisma Cosmopolitan jest używanie apostrofu przy odmianie anglicyzmów w oryginalnej postaci. Zgodnie z zasadami rodzimej ortografii dotyczy to wyrazów zakończonych niewymawianą samogłoską „e”, np. oversize'owe fasony, oversize'owa kamizelke, zachowanie określonego dress code'u, coraz więcej fanpage'ów. Należy zaznaczyć, że podane przykłady, wbrew wielu opiniom językoznawców, trudno ostatecznie uznać za świadectwo niezasymilowanych jednostek, ponieważ pomimo niezmienionej formy tematu angielskich pożyczek zostały one przypisane do konkretnego paradygmatu, nadano im przecież odpowiednią fleksję, co już świadczy o pewnym stopniu przyswojenia systemowego.

W tekstach rosyjskojęzycznych natomiast nieprzyswojone anglicyzmy bardzo często są cytowane w oryginalnej łacińskiej grafice. Taki sposób zapisu doskonale eksponuje leksykalną nowość na tle cyrylickiego tekstu, podkreślając jednocześnie jej obce pochodzenie, np. Когда хочешь почувствовать себя романтичной особой, делай ставку на total-look ивета пыльной розы [Cosmopolitan январь 2018, 41]; A в сегодняшней гастрономии все стремится $\kappa$ простой подаче. Будущее за comfort food - nростой. Доступной, сезонной едой [Cosmopolitan октябрь 2018, 272]. W przeciwieństwie do stosunkowo restrykcyjnej polityki językowej hiszpańskich normalizatorów, rosyjska kodyfikacja coraz częściej dopuszcza takie wtręty językowe do systemu języka literackiego. Dowodem tego jest umieszczanie w słownikach normatywnych wyrazów w obcej grafice (głównie anglicyzmów). 
Badanie wykazało także, że wśród odnotowanych zapożyczeń wszystkich uwzględnionych edycji znalazły się jednostki o zróżnicowanej strukturze - pojedyncze wyrazy (proste lub złożone), nazwy w postaci związków wyrazowych, a także jednostki predykatywne. Te ostatnie mogą stanowić integralny element wypowiedzenia, jednak najczęściej posiadają formę wyodrębnionych cytatów w tekście głównym lub pełnią rolę nagłówka lub hasła reklamowego, np: ros. Show must go on! Eсли ть отдыхаешь на российских курортах, братан - местный мастхэв [Соsтороlitan июль 2017, 157]; hiszp. 'Winter is coming' y toca enfrentarse al frío con estilo [Cosmopolitan noviembre 2019, 38]; pol. Wystarczy, że potaczysz charakterystyczna krate $i$ czerwień ze szlachetnymi fasonami, np. z satynowa sukienka o prostym kroju czy męska marynarka, i obowiazkowo z kozakami na płaskim obcasie. Couse punk is not dead, girl! [Cosmopolitan grudzień 2019, 70].

Warto także zwrócić uwagę na fakt, że wiele angielskich zapożyczeń we wszystkich badanych wersjach językowych posiada różne formy jednego leksemu - zaadaptowaną w nowym systemie języka i niezaadaptowaną (w postaci wtrętu językowego). Zdarza się, że na przestrzeni jednego numeru, a nawet $\mathrm{w}$ obrębie tego samego tekstu używa się obu form paralelnie. Taka sytuacja budzi pewne zastrzeżenia, bowiem mnożenie wariantów w każdym języku wywołuje konsternację czytelnika, a także komplikuje proces kodyfikacji i standaryzacji pisowni w językach narodowych.

\subsection{Przyczyny anglicyzacji/amerykanizacji języka czasopisma Cosmopolitan}

Badania procesu zapożyczania słownictwa obcego pochodzenia inspirują do rozważań na temat przyczyn tego nabierającego na sile zjawiska. Powszechnie znane są motywy transferu językowego z innych systemów. Pisało o nich wielu lingwistów, np. E. Mańczak-Wohlfeld [1995], L.P. Krysin [1968], G. Lisowska [2005], K. Luciński [2009], E.V. Marinova [2012], F. Rodríguez Gonzáles [1999]. Zgodnie upatrują oni powodów tego fenomenu w sferze języka, jak i poza nim. Powodem zapożyczania obcych jednostek jest, między innymi, potrzeba nominacji nowych desygnatów, ekonomia językowa, konieczność detalizacji pojęć, czy też chęć nadania ekspresji wypowiedzi. Poza tym zapożyczenia są efektem integracji językowej w obrębie całego świata i wszechobecnej globalizacji. Badacze języka przyznają, że rozpowszechnienie języka angielskiego i transfer leksykalny anglicyzmów odbywa się we wszystkich sferach komunikacji międzyludzkiej w zdecydowanej większości grup etnicznych na naszym globie [Березовская, Кирьянова 2009, 145]. 
Można by uznać, że temat powodów przejmowania obcojęzycznych elementów jest wyczerpany ze względu na rzeczywiście spory dorobek w danym zakresie, niemniej jednak motywacja użycia leksyki obcego pochodzenia często bywa zindywidualizowana i uzależniona chociażby od dyskursu, w jakim zachodzi sam proces zapożyczania, czy też od intencji uczestników tegoż dyskursu, a także od stopnia znajomości języka będącego źródłem zapożyczeń.

Poszukując powodów ekspansji anglicyzmów w czasopiśmie Cosmopolitan, należy uwzględnić kilka niestandardowych, istotnych faktów. Magazyny typu fashion oraz lifestyle, które stanowią istotny sektor prasy luksusowej, są produktem komercyjnym [Кулешова 2011, 54], elementem przemysłu modowego, a ich język stanowi integralną część tejże industrii. W związku z tym język odzwierciedla charakter mody światowej i jest kształtowany przez wielojęzyczne i wielokulturowe kody wpływowych stylistów i projektantów [Balteiro 2018, 23]. W języku mody anglicyzmy uwypuklają się w sposób szczególny. Isabel Balteiro [2018, 23] podkreśla, że w danym dyskursie są one wysoko cenione, kojarzone z prestiżem oraz świadczą o postępie, szybkiej ewolucji, ciągłych zmianach, kreatywności, trudach, innowacji i wszechstronności mody. Językoznawczyni dodaje, że, przykładowo, o ile w Hiszpanii inkorporację zapożyczeń angielskich do innych języków specjalistycznych uważa się za zagrożenie dla czystości języka, to jednak w języku mody pożyczki angielskie są postrzegane zgoła inaczej - ich użycie daje poczucie bycia „na czasie” i bycia „cool”, a także tworzy wrażenie przynależności do pożądanej grupy społecznej [Ibidem, 23].

Z kolei polska badaczka, Anna Kaczmarek, która przeprowadziła badanie anglicyzmów w prasie kobiecej (także w magazynie Cosmopolitan) użycia anglicyzmów upatruje $\mathrm{w}$ „chęci uatrakcyjnienia przekazu, nadania $\mathrm{mu}$ walorów prestiżowych, a także w potrzebie wzmocnienia funkcji perswazyjnej, czyli zainteresowania czytelnika w takim stopniu, by konkretny tekst prasowy „sprzedać” jako produkt” [Kaczmarek 2013, 15]. Autorka dodaje, że czytelnik czasopisma podlega wówczas pewnej nobilitacji, ponieważ autorzy tekstów używający anglicyzmów zakładają, że odbiorca jest kompetentny, bowiem zna język angielski [Ibidem]. Wskazana przez autorkę kwestia funkcji perswazyjnej zapożyczeń angielskich jest niezwykle istotna, ponieważ nie ulega wątpliwości, że sięganie do areału obcego przez dziennikarzy czy też twórców reklam ma często charakter intencjonalny, lub jak proponuje Katarzyna Wojan - nieprzypadkowy [Wojan 2010, 11]. Oznacza to, że użycie konkretnego wyrazu zapożyczonego lub bardziej złożonej struktury syntaktycznej jest całkowicie świadome, ukierunkowane na wywołanie określonej reakcji czytelnika, na stworzenie pewnej konwencji wypowiedzi. 
Na ciekawy aspekt motywacji użycia pożyczek w języku prasy zwraca uwage pionierka szerokich badań nad anglicyzmami w Polsce - Elżbieta Mańczak-Wohlfeld. Rolę rozpowszechnia pożyczek językowych przypisuje specjalistom z danej dziedziny, a także dziennikarzom, którzy, zgodnie z twierdzeniem badaczki, często używają leksyki obcej proweniencji z powodu pośpiechu towarzyszącego ich pracy [Mańczak-Wohlfeld 2005, 43]. Głównie chodzi o proces tłumaczenia z angielskiego, gdy łatwiej jest użyć „gotowego" zapożyczenia niż szukać sztucznie brzmiącego odpowiednika w języku rodzimym. Rola autorów tekstów w transferze językowym jest znacząca i, przy okazji, nie zawsze oceniana bez emocji. Natalia Kuznecova [2016, 54-55], na przykład, zarzuca wręcz hiszpańskim dziennikarzom czasopism luksusowych dedykowanych kobietom, że nie dbają oni o swoje czytelniczki, nadużywając leksyki zapożyczonej, która często w odczuciu nosicieli języka bywa niezrozumiała.

Dziennikarze używają pożyczek z różnych pobudek (Czyt. powyżej). Można także dodać, że posługiwanie się w mowie anglicyzmami wynika z elokwencji autorów, ich wykształcenia, dobrej znajomości języka i służy podkreśleniu „kolorytu narodowego” [Смеюха 2013, 93] opisywanych realiów kultury Zachodu. Często jednak zapożyczenia w „rękach żurnalistów" stają się, na przykład, narzędziem manipulacji (w tym gry językowej), czy też sposobem na odświeżenie określeń starych artefaktów. W konsekwencji deformuje się przy tym tradycyjne modele słowotwórcze, narusza utrwalone w paradygmatach szablony składniowe. Warto również podkreślić, że import i popularyzacja zapożyczeń nie jest tylko zasługą dziennikarzy i innych pracowników badanego magazynu. Język danego czasopisma nie istnieje przecież jako samodzielny byt, a raczej jest integralną częścią całego systemu językowego i ulega wpływom różnych dyskursów tworzonych przez ich uczestników. Zatem wpływ na kształt badanych języków czasopisma Cosmopolitan mają także przeciętni użytkownicy języków narodowych, których udział w kreowaniu języka jest ogromny, często wymykający się spod kontroli kodyfikatorów, a jednocześnie zupełnie naturalny.

\section{Podsumowanie}

Powyższe rozważania świadczą o tym, że czasopismo Cosmopolitan jest swoistą platformą transferu językowego z areału anglojęzycznego (głównie angloamerykańskiego). Popularność pożyczek w danym dyskursie wynika z różnych przyczyn, które raz mają charakter spontaniczny, innym razem 
zamierzony. Intencjonalność sięgania po anglicyzmy przez autorów tekstów $\mathrm{w}$ analizowanym miesięczniku jest bardzo silnie odczuwalna. Ponadto zaprezentowane przykłady pożyczek, odnotowanych w wersji polskiej, rosyjskiej i hiszpańskiej są jaskrawym przykładem realizacji kosmopolitycznej idei przyświecającej misji magazynu, a tym samym internacjonalizacji angielszczyzny. Jej globalny zasięg jest zauważalny w wielu sferach działalności człowieka, niemniej szczególnie uwypukla się w modzie, czy też w świecie, który umownie można nazwać „wirtualnym”. Uwzględniając charakter adaptacji przejętego z angielszczyzny słownictwa, można stwierdzić, że w każdym eksplorowanym języku pożyczki łatwo integrują się w nowym systemie, przypisywane są do konkretnych paradygmatów przy pomocy własnego arsenału możliwości językowych. W tekstach Cosmopolitan przejawia się tendencja do używania form nieprzyswojonych w pełni, w oryginalnej pisowni, które najjaskrawiej demonstrują swoja „obcość” i dynamikę samego procesu zapożyczania. Są one doskonałym narzędziem perswazji językowej, a także odzwierciedleniem nieustającego wciąż dążenia współczesnych społeczeństw do ujednolicenia komunikacji międzyludzkiej wynikającej z chęci bycia „obywatelami świata bez granic".

\section{Literatura}

Kaczmarek A., 2013, O kreatywnych anglicyzmach w polskiej prasie kobiecej, „Kwartalnik Językoznawczy” nr 2, s. 13-22.

Kłaczyńska A., 2010, Anglicyzmy we wspótczesnej polszczyźnie na przykładzie czasopism kobiecych oraz na tle świadomości językowej bydgoskich studentów, „Linguistica Bidgostiana”, s. 85-101.

Luciński K., 2000, Anglicyzmy w języku polskim i rosyjskim, Kielce.

Mańczak-Wohlfeld E., 1995, Tendencje rozwojowe wspótczesnych zapożyczeń angielskich w języku polskim, Kraków.

Surendra A., 2019, Moda językowa na zapożyczeni angielskie w prasie kobiecej, Poznań.

Wojan K., 2010, Przypadkowe i nieprzypadkowe wędrówki leksemów, Gdańsk.

Bajdžanova Û.Š., 2012, Âzyk glâncevyh žurnalov kak osobennost' sovremennoj massovoj kul'tury, «Vestnik Baškirskogo universiteta» t. 17, nr 3(1), s. 16411642. [Байджанова Ю.Ш., 2012, Язык глянчевых журналов как особенность современной массовой культуры, «Вестник Башкирского университета» т. 17, № 3(1), с. 1641-1642.]

Balteiro I., 2018, Non-pronominal uses of it: a case study in women's fashion magazines, "Revista de Lenguas para Fines Especificos" 24.1, s. 1-46. 
Berezovskaâ O.M., Kir'ânova L.P., 2009, Tendencii ètnoâzykovyh processov v usloviâh globalizacii sovremennogo obsestva, «Izvestiâ Tomskogo politehničeskogo universiteta» t. 315, nr 6, s. 144-148. [Березовская О.М., Кирьянова Л.П., 2009, Тенденции этноязыковых прочессов в условиях глобализации современного общества, «Известия Томского политехнического университета» т. 315, № 6, с. 144-148.]

Dianova V.M., 2007, Kosmopolitizm v èpohu globalizacii, «Voprosy kul'turologii» nr 1, s. 8-12. [Дианова В.М., 2007, Космополитизм в эпоху глобализации, «Вопросы культурологии» № 1, с. 8-12.]

Janssens M. \& Steyaert Ch., 2014, Re-considering language within a cosmopolitan understanding: Toward a multilingual franca approach in international business studies, „Journal of International Business Studies” nr 7, s. 1-16. https://www.researchgate.net/publication/312004448_Re-considering_Lang uage_within_a_Cosmopolitan_Understanding_Toward_a_Multilingual_Franca _Approach_in_International_Business_Studies [01.07.2021].

Kaûmova È.R., 2009, Osobennosti organizacii teksta v žurnale «Cosmopolitan», «Lingua mobilis»nr 3 (17), s. 131-135. [Каюмова Э.P., 2009, Особенности организации текста в журнале «Cosmopolitan», «Lingua mobilis» № 3 (17), c. 131-135.]

Krysin L.P., 1968, Inoâzyčnye slova v sovremennom russkm âzyke, Moskva [Крысин Л.П., 1968, Иноязычные слова в современном русскм языке, Москва.]

Kulešova N.A., 2010, Anglicizmy v ispanskih ženskih žurnalah, «Vestnik RUDN» nr 2, s. 34-41. [Кулешова Н.А., 2010, Англииизмь в испанских женских журналах, «Вестник РУДН» № 2, с. 34-41.]

Kulešova N.A., 2011, Âzyk mody v èpohu globalizacii (ob anglo-amerikanskih zaimstvovaniâh $v$ russkoj, ispanskoj i francuzskoj versiâh žurnala Vogue), «Vestnik RUDN» nr 1, s. 52-61. [Кулешова Н.A., 2011, Язык моды в эпоху глобализачии (об англо-американских заимствованиях в русской, испанской и французской версиях журнала Vоgие), «Вестник РУДН» № 1, c. $52-61$.

Kuznecova N.A., 2016, Ispanskâ̂ leksikografičeskâ̂ tradiciâ kodifikacii anglicizmov imediateksty o mode, «Vestnik RUDN» nr 2, s. 50-56. [Кузнецова Н.A., 2016, Испанская лексикографическая традичия кодификачии англичизмов и медиатексты о моде, «Вестник РУДН» № 2, с. 50-56.]

Lisowska G., 2005, Zaimstvovannye imena suŝestvitel'nye v sisteme russkogo slovoobrazovaniâ, Słupsk. [Lisowska G., 2005, Заимствованнье имена существительнье в системе русского словообразования, Słupsk.]

Núñez Nogueroles, E.E., 2017, Typographical Orthographic and Morphological Variation of Anglicisms in a Corpus of Spanish Newspaper Texts, „Revista Canaria de Estudios Ingleses", 75, s. 175-190.

Polonskij A.V., Samotuga E.A., 2010, Klûčevye osobennosti diskursa glâncevyh žurnalov, «Naučnye Vedomosti. Seriâ Gumanitarnye nauki»nr 18 (89), vyp. 7, s. 227-235. [Полонский А.В., Самотуга Е.А., 2010, Ключевые особенности дискурса глянцевых журналов, «Научные Ведомости. Серия Гуманитарные науки» № 18 (89), вып. 7, с. 227-235.] 
Rodríguez Gonzáles F., 1999, Anglicisms in contemporary Spanish. An overview, „Atlantis" XXI, s. 103-139.

Smeûha V.V., 2013, Ispol'zovanie inoâzyčnoj leksikiv ženskih žurnalah: funkcii $i$ osobennosti, «Ženŝina v rossijskom obŝestve» $\mathrm{nr} 1$ (66), s. 81-95. [Смеюха В.В., 2013, Использование иноязычной лексики в женских журналах: функиии и особенности, «Женщина в российском обществе» № 1 (66), c. $81-95$.]

Zinov'eva E.S., 2016, Diskurs russkoâzyčnyh glâncevyh žurnalov kak ob'ekt medialingvistiki, «Vestnik Čerepoveckogo gosudarstvennogo universiteta» $\mathrm{nr} 4$, s. 88-92. [Зиновьева Е.С., 2016, Дискурс русскоязычных глянцевых журналов как объект медиалингвистики, «Вестник Череповецкого государственного университета» № 4, с. 88-92.]

\section{FOREIGN INFLUENCES IN THE TEXTS OF GLOSSY MAGAZINES \\ IN RUSSIAN, POLISH AND SPANISH \\ (ON THE EXAMPLE OF COSMOPOLITAN)}

ABSTRACT

The focus of this paper is the impact of English observed in the language of an international magazine Cosmopolitan. The research was conducted taking into account three language versions of the monthly magazine: Russian, Polish and Spanish. Factual material was excerpted from the periodicals published in 20172021. Taking up this topic stems from the need to fill the gap in research on the language of luxury magazines, which have a great influence on forming the canons of linguistic norms and the linguistic awareness of their readers. The aim of the study is to analyze the collected Anglicisms (mainly loanwoard) in terms of their function, way of adaptation and presentation in the text space. Determining the reasons for the popularity of foreign forms in a given language space is also an important point of analysis. An additional assumption of the publication is to indicate the connections between the use of borrowings and the ideological concept of the magazine with cosmopolitanism.

Key words: anglicism, glossy magazine, media discourse, internationalism, cosmopolitanism 